\title{
Современное состояние природных кормовых угодий Михайловского района (Алтайский край)
}

\section{Current conditions of nature pastures in Mikhailovskij district (Altai Krai)}

\author{
Елесова Н. В. \\ Elesova N. V. \\ Алтайский государственный университет, г. Барнаул, Россия. E-mail: elesovanv@таil.ru \\ Altai State University, Barnaul, Russia
}

\begin{abstract}
Peфераm. Приводятся результаты геоботанического обследования природных кормовых угодий Михайловского района Алтайского края. Природные кормовые угодья района представлены настоящими дерновинно-злаковыми и разнотравно-дерновиннозлаковыми степями, разнотравно-злаковыми гликофильными и галофильными лугами разной степени нарушенности.
\end{abstract}

Ключевые слова. Геоботаника, кормовые угодья, Михайловский район, типчаковые, ковыльные степи.

Summary. The results of geobotanic survey of natural pastures of Mikhailovskij district in Altai Krai are shown. Natural pastures of the district are presented by real grasses, varies plant-grasses steppes, varies plant-grasses glikophylous and halophylous meadows on different stages of disturbance.

Key words. Geobotany, Mikhailovskij district, pastures, sheep fescue, grazer steppes.

Михайловский район расположен на юго-западе Алтайского края в степной зоне. Рельеф равнинный. Климат резко континентальный. Средняя температура января $-17,6{ }^{\circ} \mathrm{C}$, июля $+21^{\circ} \mathrm{C}$. Годовое количество атмосферных осадков - 245 мм. Почвы каштановые, с многочисленными солонцами (https://mhlaltay.ru/pages/187).

Зональным типом растительности в Михайловском районе являются степи, большей частью распаханные, оставшиеся степные участки используются для выпаса и сенокошения. Сложившаяся структура сельхозугодий района отличается завышенной долей пашни (более 2/3) и неоправданно заниженной сенокосов и пастбищ, сильно деградированных в результате ежегодного сенокошения и перевыпаса (Силантьева и др., 2012).

Природные кормовые угодья района представлены настоящими дерновинно-злаковыми и разнотравно-дерновинно-заковыми степями, разнотравно-злаковыми галофильными лугами, расположенными по понижениям и берегам соленых озер.

Степи составляют основу природных кормовых угодий Михайловского района, представлены, в основном, сообществами настоящих бедноразнотравно-дерновиннозлаковых степей, с небольшим участием луговых степей.

В 2012-2018 гг. сотрудниками кафедры ботаники Алтайского государственного университета проводилось обследование степных кормовых угодий Михайловского района, результаты приведены ниже.

\section{Ковыльные степи}

Разнотравно-типчаково-тырсоковыльная степь (N5204.150' Е79³5.390' Алтайский кр., Михайловский р-н, в 8 км на 3 от с. Полуямки), соответствует 2 стадии пастбищной дигрессии - уме- 


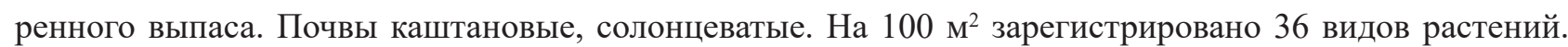
Общее проективное покрытие- 55-60 \%.Эдификаторы травостоя - овсяница валисская, типчак (Festuca valesiaca Gaudin) cop1 (10 \%), ковыль волосовидный (Stipa capillata L.) cop2 (10-15\%).

Травостой трехъярусный. Первый ярус 50-65 см образован эдификатором ковылем волосатиком (Stipa capillata), ковылем перистым (Stipa pennata L.). Второй ярус 30-40 см образован тонконогом гребенчатым (Koeleria cristata (L.) Pers.), мятликом узколистным (Poa angustifolia L.) и степным разнотравьем: подмаренником русским (Galium ruthenicum Willd.), ворсянкой бледно-желтой (Scabiosa ochroleuca L.), васильком шероховатым (Centaurea scabiosa L.), полынью серой (Artemisia glauca Pall. Ex Willd.), шалфеем степным (Salvia stepposa Shost.). В третьем подъярусе 10-15 см встречается типчак (Festuca valesiaca), лапчатка распростертая (Potentilla humifusa Willd. Ex Schlecht.), тимьян Маршалла (Thymus marschallianus Willd.), осока твердоватая (Carex duriuscula C.A. Меу), полынь австрийская (Artemisia austriaca Jack.). Из бобовых в травостое присутствуют: люцерна серповидная (Medicago falcata L.), остролодочник волосистый (Oxytropis pilosa (L.) DC.), астрагал бухтарминский (Astragalus buchtormensis Pall.), эспарцет песчаный (Onobrychis arenaria (Kit.) DC). Раннецветущие растения: козелец мелколистный (Scorsonera parviflora Jack.), астрагал бухтарминский (Astragalus buchtormensis), лапчатка простертая (Potentilla humifusa) и др.

\section{типчаковые степи}

Васильково-мятликово-типчаковая степь (N5204.151' Е79³5.390' Алтайский кр., Михайловский р-н, в 8 км на 3 от с. Полуямки), соответствует 2 стадии пастбищной дигрессии - умеренного выпаса. Почвы каштановые, солонцеватые. Общее проективное покрытие- 65-70 \%. Эдификаторы травостоя - василек шероховатый (Centaurea scabiosa) cop1 (10\%), мятлик узколистный (Poa angustifolia) cop2 (12\%), овсяница валисская, типчак (Festuca valesiaca) cop3 (15\%).

Травостой трехъярусный. Первый ярус 85 см образован васильком шероховатым (Centaurea scabiosa), ковылем волосатиком (Stipa capillata), солодкой уральской (Glycyrrhiza uralensis Fisch.) и др. Второй ярус 40 см образован тонконогом гребенчатым (Koeleria cristata), мятликом узколистным (Poa angustifolia), типчаком (Festuca valesiaca) и др. В третьем подъярусе 20 см встречается лапчатка распростертая (Potentilla humifusa), лапчатка двураздельная (Potentilla bifurca L.), полынь австрийская (Artemisia austriaca), полынь холодная (Artemisia frigida Willd.) и др. растения.

Злаки (4 вида) представлены мятликом узколистным (Poa angustifolia), типчаком (Festuca valesiaca), тонконогом гребенчатым (Koeleria cristata), ковылем волосатиком (Stipa capillata). Из бобовых (5 видов) в травостое присутствуют: люцерна серповидная (Medicago falcata), остролодочник волосистый (Oxytropis pilosa), солодка уральская (Glycyrrhiza uralensis), донник лекарственный (Melilotus officinalis (L.) Pall.), эспарцет песчаный (Onobrychis arenaria). Осоки представлены осокой низкой (Сarex supina Willd. ex Wahlenb.).

Группа разнотравья (21 вид): василек шероховатый (Centaurea scabiosa), подмаренник русский (Galium ruthenicum), ворсянка бледно-желтая (Scabiosa ochroleuca), шалфей степной (Salvia stepposa), лапчатка простертая (Potentilla humifusa), лапчатка двураздельная (Potentilla bifurca), лапчатка седоватая (Potentilla canescens Bess.), синеголовник плосколистный ((Eryngium planum L.), ушанка мелкоцветковая (Otites parviflora (Ehrh.) Grossh.), мелколепестник едкий (Erygeron acris L.), монашенка русская (Nonea rossica Stev.), тысячелистник щетинистый (Achillea setacea Waldst. ex Kit.), вероника ненастоящая (Veronica spuria L.), очанка гребенчатая (Euphrasia pectinata L.), крестовник эруколистный (Jacobaea erucifolia (L.) Gaertn.), подорожник средний (Plantago media L.).

Степные полыни: полынь австрийская (Artemisia austriaca), полынь серая (Artemisia glauca), полынь понтийская (Artemisia pontica L.). Сорные растения: икотник серо-зеленый (Berteroa incana (L.)

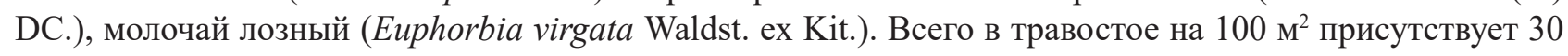
видов высших сосудистых растений.

Полынно-люцерново-типчаковая степь (N5204.156' Е79³5.391' Алтайский кр., Михайловский р-н, в 8 км на 3 от с. Полуямки). Участок полынно-люцерново-типчаковой степи находится на 3 
стадии пастбищной дигрессии (усиленный выпас, типчаковая стадия). Почвы темно-каштановые, солонцеватые. Общее проективное покрытие $-55-60 \%$.

Эдификаторы травостоя: полынь австрийская (Artemisia austriaca) cop 1 (6 \%), люцерна серповидная (Medicago falcata) cop 2 (10\%), овсяница валисская (Festuca valesiaca) cop3 (15\%).

Травостой трехъярусный. Первый ярус 70 см образован: пыреем ползучим (Elytrigia repens (L.) Nevsky), житняком гребневидным (Agropyron pectinatum (Bieb.) Beauv.), шалфеем степным (Salvia stepposa), васильком шероховатым (Centaurea scabiosa) и др.

Второй ярус 35-40 см образован злаками - тонконогом гребенчатым (Koeleria cristata), мятликом узколистным (Poa angustifolia), типчаком (Festuca valesiaca) и степным разнотравьем.

В третьем ярусе 15 см встречается лапчатка распростертая (Potentilla humifusa), змеевка растопыренная (Cleistogenes squarrosa (Trin.) Keng), полынь австрийская (Artemisia austriaca) и др.

Группа злаков (5 видов) - овсяница валисская (Festuca valesiaca), пырей ползучий (Elytrigia repens), житняк гребневидный (Agropyron pectinatum), тонконог гребенчатый (Koeleria cristata), мятлик узколистный (Poa angustifolia).

Бобовые (3 вида) представлены люцерной серповидной (Medicago falcata), донником лекарственным (Melilotus officinale), астрагалом эспарцетовым (Astragalus onobrychis L.).

Группа разнотравья (13 видов) - василек шероховатый (Centaurea scabiosa), синеголовник плосколистный (Eryngium planum), подмаренник русский (Galium ruthenicum), шалфей степной (Salvia stepposa), икотник серый (Berteroa incana), крестовник эруколистный (Jacobaea erucifolia), монашенка (Nonea rossica Stev.), тысячелистник щетинистый (Achillea setacea), грыжник многообразный (Herniaria polygama J. Gay). Полыни: полынь австрийская (Artemisia austriaca), полынь серая (Artemisia glauca), полынь Сиверса (Artemisia sieversiana Willd.), полынь селитряная (Artemisia nitrosa Web.). Осоки

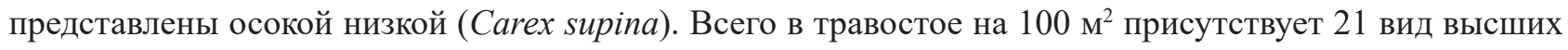
сосудистых растений.

Адонисово-полынно-типчаковая степь (N52¹0.712' Е7943.065' Алтайский кр., Михайловский р-н, в 8 км на С-3 от с. Ащегуль). Участок адонисово-полынно-типчаковой степи находится на 3 стадии пастбищной дигрессии (усиленный выпас, типчаковая стадия). Почвы темно-каштановые, солонцеватые. Общее проективное покрытие- 40-45 \%. Геоботаническое описание было выполнено 17.06.2012 г. для учета раннецветущих растений.

Эдификаторы травостоя: адонис пушистый (Adonis villosa Ledeb.) cop 1 (7 \%), полынь холодная (Artemisia frigida) cop 2 (10 \%), овсяница валисская (Festuca valesiaca) cop3 (15\%).

Травостой трехъярусный. Первый ярус 27-30 см образован: подмаренником русским (Galium ruthenicum), полынью серой (Artemisia glauca), прострелом раскрытым (Pulsatilla patens (L.) Mill.) и др.

Второй ярус 15 см образован адонисом пушистым (Adonis villosa), типчаком (Festuca valesiaca), кострецом безостым (Bromopsis inermis (Leuss.) Holub.), мятликом узколистным (Poa angustifolia), полынью серой (Artemisia glauca) и степным разнотравьем.

В третьем ярусе 5-7 см встречаются вегетативные побеги: полыни холодной (Artemisia frigida), синеголовник плосколистный (Eryngium planum), тысячелистник благородный (Achillea nobilis L.), василек шероховатый (Centaurea scabiosa), василек сибирский (Centaurea sibirica L.), тимьян Маршалла (Thymus marschallianus) и др.

Группа злаков (5 видов) - овсяница валисская, типчак (Festuca valesiaca), житняк гребневидный (Agropyron pectinatum), мятлик узколистный (Poa angustifolia), кострец безостый (Bromopsis inermis), ковыль волосовидный (Stipa capillata). Бобовые (4 вида) представлены люцерной серповидной (Medicago falcata), астрагалом яичкоплодным (Astragalus testiculatus Pall.), остролодочником волосистым (Oxytropis pilosa (L.) DC.), солодкой уральской (Glycyrrhiza uralensis).

Группа разнотравья (16 видов) - василек шероховатый (Centaurea scabiosa), василек сибирский (Centaurea sibirica), синеголовник плосколистный (Eryngium planum), подмаренник русский (Galium ruthenicum), шалфей степной (Salvia stepposa), икотник серый (Berteroa incana), монашенка (Nonea rossica), тысячелистник благородный (Achillea nobilis), адонис пушистый (Adonis villosa), прострел раскрытый (Pulsatilla patens), молочай лозный (Euphorbia virgata), тимьян Маршалла (Thymus marschal- 
lianus), лапчатка двураздельная (Potentilla bifurca), лапчатка седоватая (Potentilla canescens). Степные полыни: полынь австрийская (Artemisia austriaca), полынь серая (Artemisia glauca), полынь холодная (Artemisia frigida). Осоки представлены осокой низкой (Carex supina), из лишайников присутствует пармелия влагалищная (Parmelia vagans), из кустарников - спирея городчатая (Spiraea crenata L.). Раннецветущие растения: адонис пушистый (Adonis villosa), прострел раскрытый (Pulsatilla patens), астра-

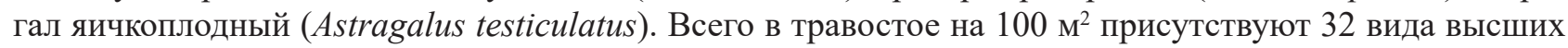
сосудистых растений.

\section{Полынные степи}

Tипчаково-полынная степь (N5204.156' Е79³5.395' Алтайский кр., Михайловский р-н, в 8 км на 3 от с. Полуямки), соответствует 4 стадии пастбищной дигрессии (полынная стадия), почти полностью уничтожена степная подстилка. Почвы темно-каштановые, солонцеватые. Общее проективное покрытие- 45 \%. Типчаково-полынные, холоднополынные и австрийскополынные степи распространены вдоль степных дорог, у деревень, скотных дворов и летних площадок КРС.

Эдификаторы травостоя: овсяница валисская сор 2 (15\%), (Festuca valesiaca), полынь австрийская (Artemisia austriaca) cop3 (18\%). В травостое условно можно выделить 2 яруса. Первый ярус 45 см образуют: качим метельчатый (Gypsophylla paniculata L.), полынь замещающая (Artemisia commutata Bess.). Второй ярус 20-25 см образуют все остальные степные растения: злаки (типчак, житняк гребневидный (Agropyron pectinatum)), люцерна серповидная (Medicago falcata), полынь австрийская (Artemisia austriaca), полынь холодная (Artemisia frigida), икотник серозеленый (Berteroa incana), подмаренник русский (Galium ruthenicum), одуванчик бессарабский (Taraxacum bessarabicum (Hornem.)

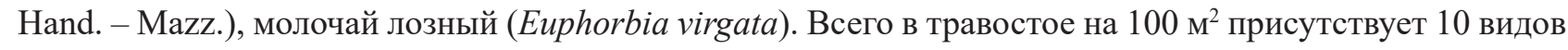
высших сосудистых растений.

\section{Мятликовые степи}

Люцерново-типчаково-мятликовая степь (N5209.345' E7955.426' Алтайский кр., Михайловский р-н, в 8 км на В от с. Ащегуль).

Эдификаторы травостоя: люцерна серповидная (Medicago falcata) cop 1 (10\%), овсяница валисская (Festuca valesiaca) cop 2 (20\%), мятлик узколистный (Poa angustifolia) cop3 (25\%).

Травостой трехъярусный. Первый ярус 40 см образован луговостепным разнотравьем: зопником клубненосным (Phlomis tuberosa L.), смолоносницей джунгарской (Ferula soongarica Pall. Ex Spreng.), качимом метельчатым (Gypsophilla paniculata), лабазником обыкновенным (Filipendula vulgaris Moench), лапчаткой золотистой (Potentilla chrysantha Trev.), вероникой ненастоящей (Veronica spuria L.) и др. Второй ярус 25-30 см образован люцерной серповидной (Medicago falcata), подмаренником русским (Galium ruthenicum), горичником Мориссона (Peucedanum morissonii Bess. Ex Spreng.), ворсянкой бледно-желтой (Scabiosa ochroleuca), шалфеем степным (Salvia stepposa и др. В третьем подъярусе 1518 см встречается мятлик узколистный (Poa angustifolia), типчак (Festuca valesiaca), вероника седая (Veronica incana L.), лапчатка двураздельная (Potentilla bifurca), тимьян Маршалла (Thymus marschallianus), полынь серая (Artemisia glauca), полынь холодная (Artemisia frigida) и др. Из бобовых в травостое присутствуют: люцерна серповидная (Medicago falcata), чина луговая (Lathyrus pratensis L.).

Группа разнотравья (25 видов) - подмаренник русский (Galium ruthenicum), шалфей степной (Salvia stepposa), зопник клубненосный (Phlomis tuberosa), смолоносница джунгарская (Ferula soongarica), качим метельчатый (Gypsophilla paniculata), лабазник обыкновенный (Filipendula vulgaris), лапчатка золотистая (Potentilla chrysantha), вероника ненастоящая (Veronica spuria), адонис пушистый (Adonis villosa), молочай лозный (Euphorbia virgata), тимьян Маршалла (Thymus marschallianus), лапчатка двураздельная (Potentilla bifurca), подорожник Урвиллея (Plantago urvillei Opiz), вероника седая (Veronica incana), полынь австрийская (Artemisia austriaca), полынь серая (Artemisia glauca), полынь хо-

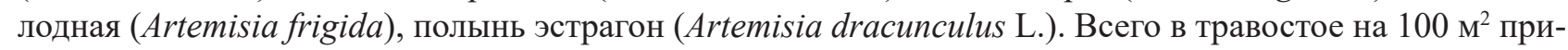
сутствует 30 видов высших сосудистых растений. 
Ковыльные степи в настоящее время являются редкими типами растительности, наиболее распространенными кормовыми угодьями являются злаково-типчаковые и полынно-типчаковые степи, у деревень распространены сильно деградированные холоднополынные и австрийскополынные степи.

\section{ЛИТЕРАТУРА}

Географическое положение. Администрация Михайловского района. URL: https://mhlaltay.ru/pages/187 (Дата обращения 29.04.2019)

Силантьева М. М., Елесова Н. В., Шибанова А. А., Гребенникова А. Ю. О современном состоянии степной растительности степной и лесостепной зон Алтайского края // Известия Алтайского государственного университета, 2012. - № 3/1(75). - С. 78-84. 